\title{
POTENTIA
}

Journal of International and Public Affairs - Fall 2020 - Issue 11

Revue des affaires publiques et internationales - Automne 2020 - Numéro 11

\section{Table of content | Table des matières}

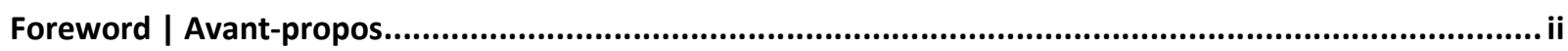

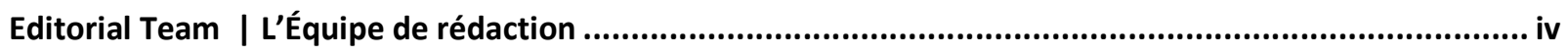

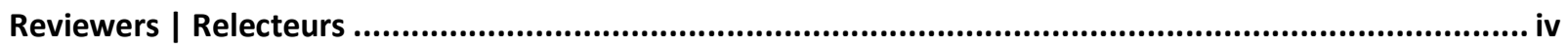

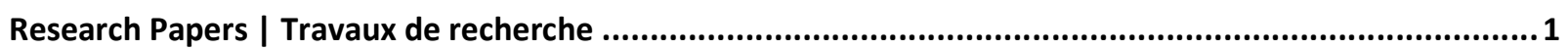

Russia's Foreign Energy Policy Towards the European Union : Prospects for Cooperation and Conflict....... 2 Riley Black

Why Libya, but not Syria? The Authorization of Military Intervention by the United Nations Security Council

Andrea Caruso

"We Are Not Getting the Good Stories Out": Québec Media Coverage and NATO`s Strategic Narrative for the International Assistance and Security Force (ISAF).

Patricia Aya Dufour

Closing the Arab Democratic Gap : A Re-Assessment of the Tunisian Democratic Transition Yolaine Frossard de Saugy

The Travails of Women and Girls in Northern Nigeria: A Human Rights Issue 53 Adah Ogbe

Inde-Afrique, un partenariat gagnant-gagnant? Thierry Santime

Policy Briefs | Notes de politique

A Narrative Analysis of Basic Income Pilots from an Ontarian Perspective. Spencer Bridgman

The Canada-US Border: Approaches to Managing Irregular Crossings. Alexa Kirkey

Book Reviews | Recensions d'ouvrage. .86

Jamie Frueh (ed). 2020. Pedagogical Journeys through World Politics. London: Palgrave Macmillan. .87 Michael P. A. Murphy

Jeffrey, C. (2010). Timepass: Youth, Class, and the Politics of Waiting in India. Palo Alto: Stanford University Press.

Étienne Tardif-Paradis

Roach, K. (2019). Canadian Justice, Indigenous Injustice: The Gerald Stanley and Colton Boushie Case.

McGill-Queen's University Press.

Dalia F. Zahreddine 